vocational guidance should still be regarded as at the experimental stage" though "sufficiently encouraging to justify the continuance of experiments". It is therefore recommended that the Industrial Health Research Board in co-operation with the Ministry of Labour should carry out further experiment. Various suggestions are made for the coordinating of existent services and for a better interchange of information between the various bodies concerned.

\section{Present and Past World Problems}

Dr. Nicholas Murray Butler has been protesting, in an address delivered at Columbia University's summer session convocation on August 7, against the absurdity of treating the world problems of our time as if they were unprecedented-as if there had been no tests in the past of theories and ideals of social, economic and political life as applied to conditions fundamentally similar. Between 1776 and 1789, the thirteen American States faced every single problem which the nations of the world face to-day. What those sovereign States were doing then, indulging in internecine tariff wars, boycotts, export prohibitions, pandering to short-sighted prejudices and particularist passion, the sovereign nations of the world are doing now. The substantial identity of the problems and of the futile tactics with which it was sought to circumvent them are illustrated by passages quoted from the works of F. S. Oliver and John Fiske and from State papers. It was Alexander Hamilton who, combining an acute intelligence, assiduous study, varied experience, indomitable courage, tenacity of purpose, persuasive eloquence and whole-hearted devotion to ideals, saved the States from the ruin towards which they were drifting, and it is by the application of the spirit of his policies to the needs of the nations of the world to-day that these may yet be saved from the world chaos with which we are threatened. The title of the address is "The World needs another Alexander Hamilton".

\section{Work of the Meteorological Office}

THE annual report of the Director of the Meteorological Office for the year ended March 31, 1934 (London: H.M. Stationery Office. 1s. net) is on the same general lines as previous reports, but is somewhat longer, numbering sixty pages; this expansion has its counterpart in an all-round increase in the activities of most of the different sections of the Office, in particular as regards the number of persons or institutions that were supplied with meteorological information, particulars of which are given in the report. In one respect, however, this report differs from those of recent years; it is made more self-contained by a modification of the introductory matter into a fairly detailed exposition of the normal work of the Meteorological Office, especially that part of it connected with synoptic meteorology which involves the collection of data broadcast by foreign countries and by ships at sea, and the supply of such data for the British Isles and neighbouring seas in return; little or no know. ledge of such matters is assumed on the part of the reader. The statisties relating to the work performed in response to external demands for information show in some cases a striking rate of increase ; for example, the forecast service dealt with 10,166 inquiries for the Press compared with 8,705 in the previous year, an advance that cannot wholly be explained by the abnormal weather of 1933-34, although this was doubtless partly responsible for it. In the section concerned with British climatology, where inquiries about past weather, some of which are of a very detailed character, are dealt with, the number of such inquiries was 2,222, and it is stated that in comparison with the annual figure ten years back, this represents a six-fold increase. The report not only summarises the activities of the branches of the Office at headquarters, located in Kingsway, London, and at Exhibition Road, South Kensington, but also those of the observatories and of the branches in Scotland, Malta, Egypt and Iraq.

\section{Co-operation between Aeronautics and Meteorology}

AN interesting case of co-operation between scientific workers to their mutual advantage is revealed in the annual report of the Meteorological Office. The Royal Air Force has established a meteorological flight at Duxford Aerodrome, Cambridge, which consists of two aeroplanes with the necessary pilots and ground staff. Their particular duty is to collect information regarding the upper air, and flights are made daily to heights of $25,000-30,000$ feet. These flights often involve penetrating cloud layers several thousands of feet thick, and such is the keenness of the station personnel that more than 90 per cent of the scheduled flights have been completed during the past year. Information developed. from this is prepared specially for civil flying and distributed from such centres as Croydon. The report states "The rapid growth of flying in and above clouds on the Continental air routes, and the practice of following a direct compass course between the terminal aerodromes, have necessitated the forecasting of much more critical conditions than formerly. Consequently the work at Croydon has become highly specialised and necessitates forecasters of considerable experience of the peculiarities of these air routes, which - in the opinion of pilots of wide experienceare the most difficult from a meteorological point of view of any in the world". 336 gale warnings were issued during the year, of which 81 per cent were justified. It has also been established that there is a fair measure of agreement between the frequency of thunderstorms and the occurrence of sunspots in high northern and tropical latitudes, though not so marked in the temperate zones.

\section{Biological Field Station near Sydney}

ThE Sydney University Biological Society has recently opened a field research station at Narrabeen, the erection and fitting of which was accomplished at a very modest cost by members of the Society and of the Sydney University Rover Scouts ; the building

(Continued on page 623.) 
contains a workroom, kitchen, verandah, and dormitory accommodation, etc. The site is about half an hour's walk from the Narrabeen tram terminus, and is within easy reach of French's Forest, Kuring-gai Chase, Deep Creek and Long Reef. It provides therefore an excellent centre for the study in their native habitats of the fauna and flora of sandstone scrub, forest, palm groves, fresh-water swamps, lagoons and beaches. The neighbourhood is also a sanctuary for native birds The research work to be done at this station, which is the first of its kind to be founded in Australia, will range from simple individual work to extended studies by teams of observers, in which botanists, zoologists and geologists may all take part. Among interesting researches which stand to the credit of senior members of the Society are Prof. W. J. Dakin's work on the food and breeding habits of the fish in Australian coastal waters, and Prof. T. G. B. Osborn's researches on Australian native fodder plants and grasses. The new station will also allow biological students to carry out under ideal conditions the field work which forms part of their training.

\section{Early Plant Hybridisation}

Further records of plant hybridisation before Kölreuter are given by Dr. C. Zirkle $(J$. Heredity, 25, No. 1), his earlier studies of this subject having been reviewed in NATURE of March 18, 1933, p. 393. Many early writers noted different coloured grains on the same ear of maize, the earliest recorded being by Tabernaemontanus (1588). Cotton Mather, in a letter to James Petiver in 1716, which is preserved in the Sir Hans Sloane collection of the British Museum, described natural crossing between different colour varieties of maize. This letter is published in full. Crossing in Cucurbita was also described. Thomas Fairchild is generally credited with having produced the first artificial plant hybrid, about 1716 . From records of Richard Bradley and the minutes of the Royal Society it is concluded that the hybrid first appeared spontaneously, and was then produced by crossing a carnation as female with the pollen of a Sweet William. Bradley himself recorded Auricula hybrids in 1717 and commented on the effect of foreign pollen in several varieties of apples and melons. Other English hybridisers of the same period are Thomas Knowlton, whose observations on Dianthus species hybrids were reported to the Royal Society in 1720; Thomas Henchman, Prebendary of Salisbury, who in 1729 noted the crossing of pea varieties and the occurrence of blue and white seeds in the same pod; and Benjamin Cooke, who in the Isle of Wight described crossing between maize varieties in 1749 (Phil. Trans. Roy. Soc., vol. 46). Twelve different investigators have now been found who described plant hybridisation before Kölreuter.

\section{Spread of the Water Hyacinth}

IN tropical waters, the water hyacinth, Eichhornia crassipes, Solms., a native of South America, a freely floating or loosely attached water plant supported by its curious buoyant bladder-like petioles, very readily becomes a serious pest, blocking waterways to navigation and converting fertile land near the waterways into stagnant swamps. F. P. Jepson, controller of plant pests, Department of Agriculture, Ceylon, has directed attention to the spread of this pest (Trop. Agric., 81, Dec. 1933). Introduced into Ceylon in 1905, probably as an ornamental plant, it has spread until in 1933 it ranges over some thousands of acres of water, paddy and swamp. At present, the infested areas lie within the inhabited zones, but Mr. Jepson contemplates with dismay the possible results of its finding its way to the vast uninhabited regions traversed by some of the larger rivers. Chemical methods of extinction are still being experimented with, but until now removal by hand has been most effective, the weed being then piled up and burnt. The chief difficulty in the control of the pest has been the apathy of the landowners and others responsible for the irrigation dams and water tanks. For this reason, Mr. Jepson's account is written in an educational and propagandist spirit, and makes clear the necessity for co-operation between private individual and Government if the water hyacinth is to be brought under control.

\section{"Marmite"}

THE yeast extract "Marmite" has long been recognised as a source of the vitamin $\mathrm{B}$ complex; more recently it has been found of value in various types of anæmia. Marmite has been compared directly with the international standard vitamin $\mathbf{B}_{1}$ preparation and found to contain 840 international units per oz., so that it is a potent source of this vitamin. It contains also vitamin $\mathrm{B}_{2}$ and other substances extractable from yeast, among which may be mentioned the 'extrinsic' factor required for normal blood formation. It is now generally considered that normal hæmatopoiesis depends upon the interaction of an 'intrinsic' factor present in the juice secreted by a healthy human stomach and an extrinsic factor present in the food : the compound formed by the interaction of these two factors is stored in the liver. In true pernicious anæmia, there is a deficiency in the secretion of the intrinsic factor, so that cure can only occur when the complete hæmatopoietic factor is supplied, as by giving liver or a preparation of it. In other anæmias, such as tropical macrocytic anæmia, it appears that the intake of the extrinsic factor is deficient ; cure can then be brought about by administering marmite. The effectiveness of marmite in anæmia is not due apparently to any constituent of the vitamin B complex present in the extract. Marmite is supplied by the Marmite Food Extract Co., Ltd., London, E.C.3.

\section{Fog Peril to Fishermen Lessened}

The United States fishermen who use dories (small flat-bottomed boats) to fish on the Grand Banks run a serious risk of drifting out to sea in a fog. This danger can now be very successfully overcome by the use of small radio transmitting sets weighing $20 \mathrm{lb}$. which can signal the position of the scattered 